\title{
Struktur Internal dan Validitas Konstruk dari Toronto Alexithymia Scale (TAS-20) dengan Sampel Mahasiswa pada Universitas di Jakarta
}

\author{
Putri Lenggo Geni \\ FakultasPsikologi UIN SyarifHidayatullah Jakarta, Indonesia \\ lenggogeniI95@gmail.com
}

\begin{abstract}
Alexithymia is a situation of extreme activity in relation to emotions, they seem insensitive to the surrounding environment. Subjects with alexithymia tendencies have difficulty identifying, describing, and interpreting their own feelings. At this time there are 2 measuring devices that are already well known alexithymia in the world, namely: Bermond Vorst Alexithymia Quastionaire (BVAQ) and Toronto Alexithymia Scale (TAS-20). From the existing literature, the more widely used is TAS-20 which consists of 20 items, to measure three dimensions, namely Difficulty Identifying Feeling (DIF), Difficulty Describing Feeling (DDF) and Externally Oriented Thinking (EOT). This research re-examines whether the existing dimensions do represent measurements of alexithymia in accordance with its operational definition. The subject of this study was a sample of a normal adult population of 250 adults, taken using non-probability sampling techniques from four universities in Jakarta. The author finds that the three dimensions conceptualized in TAS-20 are somewhat blurred, and the EOT dimension tends to dominate. In testing with a onefactor model (unidimensional), even with the assumption that all items are parallel, it turns out to be compatible with the data. But only I6 of the 20 TAS-20 items meet this requirement. That is, for the sake of scoring it would be more appropriate if the three dimensions were considered to be absent, and the use of a score obtained from the sum of a score of each item could be justified. Some suggestions are given for the use of TAS-2O in Indonesia.
\end{abstract}

Keywords: internal structure; construction validity; TAS-20; general population

\begin{abstract}
Abstrak
Alexithymia adalah situasi aktivitas ekstrim yang dalam kaitannya dengan emosi, mereka terlihat tidak peka terhadap lingkungan sekitar. Subjek dengan kecenderungan alexithymia mengalami kesulitan mengidentifikasi, mendeskripsikan, dan menginterpretasikan perasaannya sendiri. Pada saat ini ada 2 alat ukur alexithymia yang sudah cukup dikenal didunia yaitu: Bermond Vorst Alexithymia Quastionaire (BVAQ) dan Toronto Alexithymia Scale (TAS-20). Dari literatur yang ada, yang lebih banyak digunakan adalah TAS-20 yang terdiri dari 20 items, untuk mengukur tiga dimensi yaitu Difficulty Identifying Feeling (DIF), Difficulty Describing Feeling (DDF) dan Externally Oriented Thinking (EOT). Penelitian ini menguji kembali apakah dimensi yang ada itu memang mewakili pengukuran terhadap alexithymia sesuai dengan definisi operasionalnya. Subjek penelitian ini merupakan sampel dari populasi orang normal yang berusia dewasa awal berjumlah 250 orang, yang diambil menggunakan teknik non-probability sampling dari empat Univeritas di Jakarta. Penulis menemukan bahwadari tiga dimensi yang dikonsepkan pada TAS-20 agak kabur batasannya, dan dimensi EOT cenderung mendominasi. Pada pengujian dengan model satu faktor (unidimensional), bahkan dengan disertai asumsi bahwaseluruh item bersifat paralel, ternyata fit dengan data.Tetapi hanya 16 dari 20 item TAS-20 yang memenuhi syarat ini. Artinya, untuk kepentingan skoring akan lebih tepat jika tiga dimensi tersebut dianggap tidak ada, dan penggunaan sekor yang diperoleh dari penjumlahan sekor setiap item dapat dibenarkan. Beberapa saran diberikan bagi penggunaan TAS-20 di Indonesia.
\end{abstract}

Kata Kunci: struktur internal; validitas konstruk; TAS-20; general population 


\section{Pendahuluan}

Konstruk alexithymia dikembangkan oleh Sifneos (1973) dan berakar dari bahasa Yunani, yang berarti 'tidak ada kata untuk emosi' ( $\mathrm{a}=$ kekurangan, lexis $=$ kata, thymos $=$ mood atau emosi). Pada tingkat terluasnya, alexithymia menunjukkan defisit kognitif dan afektif dalam cara individu mengenali dan mengkomunikasikan keadaan emosional (Krystal, 1979). Secara kognitif, individu dengan alexithymia menggunakan gaya berpikir yang konkret dan praktis (de M'uzan, 1974), dan secara afektif, mereka menunjukkan kesadaran emosional yang berkurang dan kurang mampu membedakan (Krystal, I979).

Alexithymia adalah ketidakmampuan untuk mengenali atau menggambarkan emosi pada diri sertaseseorang. Alexithymia adalah karakteristik kepribadian di mana individu tidak dapat mengidentifikasi dan menggambarkan emosi mereka. Fitur utama alexithymia adalah ketidaksadaran emosional, kurangnya keterikatan sosial, dan hubungan interpersonal yang buruk. Selanjutnya, mereka yang menderita alexithymiaakan mengalami kesulitan mengenali dan memahami emosi orang lain (Sifneos, I973).

Alexithymia adalah ketidakmampuan untuk mengidentifikasi dan mendeskripsikan emosi diri dan orang lain. Meskipun individu dengan alexithymia menampilkan respon fisik yang khas yang terkait dengan emosi seperti air mata, butterfly in my tummy atau peningkatan denyut jantung - mereka tidak dapat mengenali tanggapan ini dalam hal emosi mereka (Thompson, 2009).

Menurut Reusch tahun 1948 dalam (Timoney, 2013). Alexithymia pertama kali dicatat, ia mengamati apa yang ia sebut sebagai 'kepribadian infantil'. Ini terjadi pada pasien yang memiliki kemampuan yang belum matang untuk mengenali dan menggambarkan dengan benar emosi mereka dan siapa yang sebaliknya akan bergantung pada isyarat eksternal untuk menentukan apa reaksi yang sesuai.

Ciri-ciri alexithymia yaitu seperti kesulitan mengidentifikasi perasaan dan membedakan antara perasaan dan sensasi tubuh, kesulitan mendeskripsikan perasaan kepada orang lain, imajinasi terbatas dan, oleh karena itu, sedikit atau tidak ada fantasi dan mimpi terbatas, dan ketidaktahuan apa yang terjadi dalam pikiran mereka sendiri dan cara berpikir yang sangat konkret (Sifneos, I973).

Seperti penelitian Michael S., Hendryx, Havilan, Dale G., Shaw (I99I), menghasilkan faktor penyebab alexithymia yaitu anxiety dan depresi. Pada penelitian Marko Manninen et.al (20II), yang menjadi fktor penyebab alexithymia adalah Anxiety, depresi, masalah pikiran dan masalah perhatian.

Alexithymia adalah bukan diagnosis, tetapi konstruk yang berguna untuk mengkarakterisasi pasien yang tampaknya tidak memahami perasaan yang dialaminya serta tampak kekurangan kata-kata untuk menggambarkan perasaan tersebut.Taylor et al. (1985) menyatakan: "pasien alexithymic mengalami kesulitan menggambarkan perasaan mereka, gaya kognitif mereka adalah konkret dan berbasis realitas, dan mereka telah memudarkan kehidupan emosional dan fantasi". Konstruk alexithymia awalnya merupakan konstelasi penyakit kepribadian (Fischer, 1997).

Alexithymia merupakan konstruk kepribadian yang menggambarkan kesulitan dalam regulasi afek dan dikenal sebagai satu dari faktor pemicu gangguan medis dan psikiatris (Taylor, Bagby \& Parker, 1989). Konstruk alexithymia meliputi empat fitur utama berikut: (I) kesulitan mengidentifikasi dan menggambarkan perasaan subjektif, (2) kesulitan membedakan antara perasaan dan sensasi fisik dari rangsangan emosional, (3) proses imajinatif terbatas, dan (4) eksternal- gaya kognitif berorientasi (Nemiah et al., 1976).

Pengukuran terhadap alexithymiasecara sistematik dan terstandarisasi yang pertama kali dikenal adalah Beth Israel Questionnaire (BIQ) yang dikembangkan oleh Sifneos (I973). Alatukur ini terdiri dari 17 pertanyaan yang disajikan dalam bentuk "force choice" yang kemudian dimodifikasi oleh Bagby, et.al. (I994) dengan 
menghilangkan sembilan pertanyaan yang tidak berhubungan dengan alexithymia, dan menambahkan empat item baru yang menargetkan alexithymia. Hasilnya adalah BIQ I2-item (revised) terdiri dari enam pertanyaan menargetkan kesadaran emosional, dan enam pertanyaan mengenai aktivitas imajinal dan berpikir operatif. Setelah itu ada pula kuesioner alexithymia Bermond-Vorst (BVAQ) (Bermond, I998) yang berevolusi dari kuesioner Amsterdam 20-item yang dimaksudkan untuk menilai lima elemen alexithymia. Bermond dan Vorst memperluas kuesioner dengan tujuan memiliki dua versi paralel, yang mengarah pada penciptaan 40-item BVAQ. Kuisioner ini mengukur sifat-sifat kepribadian yang terkait dengan pengalaman, verbalisasi, berfantasi, identifikasi, dan pemikiran tentang emosi.

Instrumen yang terakhir dan paling banyak digunakan dalam mengukur alexithymia adalah Toronto Alexithymia Scale (TAS-20) yang dikembangkan oleh Bagby, Taylor dan Parker (1994),yang mengukur tiga dimensi alexithymia.TAS-20 terdiri dari 20 item untuk mengukur tiga dimensi alexithymia yaitu: 7 item mengukur Difficulty Identifying Feeling (DIF), 5 item mengukur Difficulty Describing Feeling (DDF) dan 8 item yang mengukur Externally Oriented Thinking (EOT). Pada instrumen ini, Skor yang tinggi menunjukkan tingkat alexithymia yang semakin tinggi.

Dari ketiga alat ukur alexithymia di atas, TAS-20 lah yang paling banyak digunakan, mungkin karena lebih mudah ditafsirkan dan selain itu TAS-20 ini lebih mudah digunakan karena hanya terdiri dari 3 dimensi, sehingga terdapat lebih banyak itempada setiap dimensinya. Dari ketiga alat ukur tersebut belum ada yang pernah diterjemahkan kedalam Bahasa Indonesia untuk digunakan oleh para psikolog di Indonesia, dan belum ada yang melaporkan hasil uji validitas konstruk maupun konsistensi dari struktur internal yang dikonsepkan oleh pembuatnya. Oleh sebab itu penulis ingin menguji kembali validitas dari TAS-20 versi Bahasa Indonesia.

\section{Metode}

\section{Prosedur}

Alat Ukur yang digunakan dari Toronto Alexithymia Scale (TAS-20) diterjemahkan kedalam Bahasa Indonesia yang mudah dipahami tanpa menghilangkan arti dari konteks asli nya, dengan cara: dilakukan oleh peneliti dengan berkonsultasi kepada psikolog dan ahli yang menguasai Bahasa Inggris dan Bahasa indonesia, kemudian terjemahan tersebut di review oleh orang yang berbeda dengan meninjau dari segi Bahasa inggris dan substansi teori psikologi dalam hal ini alexithymia, kemudian instrumen yang terdiri dari 20 butir soal diberikan kepada 250 orang.

\section{Subjek}

Kelompok mahasiswa aktif tingkat sarjana disekitar Jakarta berpartisipasi dalam studi ini dan terdiridari 250orang. Subjek penelitian ini diambil menggunakan teknik non probability sampling dari empat kampus besar di Jakarta yaitu UIN Syarif Hidayatullah Jakarta, Universitas Indonesia, Universitas Pertamina dan IISIP Jakarta. Gambaran umum sampel penelitian dapat dilihat pada tabel I. 
Tabel I. Gambaran Umum Subjek Penelitian

\begin{tabular}{lll}
\hline & & Sampel N=250 \\
\hline UIN Syarif Hidayatullah & 20 tahun & 75 \\
Jakarta & 2I tahun & 25 \\
& 22 tahun & 25 \\
Universitas Indonesia & $2 \mathrm{I}$ tahun & 50 \\
Iniversitas Pertamina & 20 tahun & 50 \\
IISIP Jakarta & 22 tahun & 25 \\
Laki-laki & & I25 \\
Perempuan & & I25 \\
\hline
\end{tabular}

\section{Prosedur Statistikal}

Dalam rangka mengungkapkan struktur internal serta pengujian terhadap validitas konstruk dari TAS-20, penulis menggunakan metode CFA (Confirmatory Factor Analysis) (Joreskog, 1996). Dengan menggunakan CFA, teori yang dikatakan oleh Bagby et.al., bahwa alexithymia terdiri dari 3 dimensi dapat diuji kembali secara empiris. Langkah-langkah dalam CFA adalah: menetapkan spesifikasi model yang dalam hal ini terdiri dari 3 dimensi, kemudian dengan menggunakan CFA peneliti menguji apakah model 3 faktor (dengan komposisi dan jumlah item pada masing-masing faktor adalah sesuai dengan aslinya), adalah fit dengan data. Sebelum model tiga faktor diuji validitasnya, terlebih dahulu dilakukan uji validitas sejauh mana butir- butir soal pada masing-masing dimensi memang mengukur dimensi yang dimaksudkan, Dalam hal ini, penulis menguji apakah model unidimensional (satu faktor) fit dengan data. Prosedur ini dilakukan pada setiap dimensi yang ada. Hanya item-item yang valid dan signifikan dalam mengukur dimensi yang ditargetkan yang akan digunakan untuk analisis pada model tiga faktor. Dengan demikian ada kemungkinan tidak semua item tersebut valid dan mungkin ada yang di drop. Metode untuk menentukan apakah sebuah item tersebut akan di drop atau tidak adalah pertama, dengan menguji bahwa model unidimensional fit dengan data, dan tidak ada butir soal yang muatan (loading) faktornya negatif, serta tidak ada residual yang berkorelasi satu sama lain. Setelah itu dilihat apakah koefisien muatan faktor dari setiap item adalah signifikan secara statistikal. Jadi item yang di drop adalah jika koefisiennya negatif dan jika koefisiennya positif tapi tidak signifikan. Hanya item yang koefisiennya positif dan secara statistik signifikan yang akan diikutkan pada analisis CFA dengan model tiga faktor. Setelah diperoleh model tiga faktor yang fit dengan data, barulah hasilnya ditafsirkan apakah memang TAS-20 memiliki struktur internal seperti yang dikonsepkan oleh pembuatnya serta apakah semua itemnya memang valid mengukur dimensi yang ditargetkan. Jelas tergambar di sini bahwa dalam penggunaan CFA pengambilan keputusan sangat ditentukan oleh pemilihan indeks pengujian model fit (test of goodness of fit ) yang digunakan. Menurut Joreskog (1996) yang sebenarnya paling tepat dan mudah digunakan dalam hal ini adalah Chi-Square. Namun ia juga mengemukakan bahwa dalam hal ini besaran nilai Chi-Square yang diperoleh merupakan fingsi langsung dari besarnya sampel yang digunakan untuk mengestimasi nilai parameter dari model yang diuji. Makin besar sampel, akan makin besar nilai Chi-Square yang berarti akan makin kecil kemungkinan untuk mendapatkan model fit. Akibatnya besar kemungkinan untuk menolak model yang sebenarnya cukup fit dengan data yang ada. Oleh sebab itu dalam penelitian ini penulis menggunakan indeks RMSEA (Root Mean Square Error of Approximation) sebagai kriteria utama dalam menentukan apakah model fit dengan data. Alasannya (Joreskog, 1996) adalah karena RMSEA relatif tidak dipengaruhi oleh besarnya sampel namun tetap merupakan indeks yang bersifat parametrik (berbasis populasi) sehingga dapat dilakukan tes signifikansi. Meskipun banyak tersedia indeks yang lain namun umumnya tidak bersifat parametrik (hanya berbasis sampel) dan tak ada uji probabilitas tentang signifikansinya. Adapun model dapat dikatakan fit dengan melihat tiga hal yaitu: (I) apabila nilai RMSEA $<$ 0.05, atau (2) jika batas bawah dari 90 percent Confident Interval (C.I.) dari RMSEA < 0.05, atau (3) jika probability bahwa RMSEA $<0.05$ adalah lebih besar dari lima persen $(p>0.05)$. Apabila satu atau lebih dari tiga kriteria tersebut terpenuhi maka model dapat dinyatakan fit dengan data. Alternatif lain adalah dengan menggunakan pendekatan Item Response Theory di mana yang digunakan sebagai indeks untuk model fit 
adalah Likelihood Ratio Chi-Square yang derajat kebebasan (DF) nya tidak berbasis sampel subyek, tetapi dihitung berdasarkan banyaknya pola respons terhadap seluruh butir soal yang ada. Dengan software MPLus semua indeks yang disebutkan di sini dapat diperoleh (Muthén \& Muthén (20I2)).

\section{Hasil dan Pembahasan}

\section{Dimensi I: DIF (Difficult Identifying Feeling)}

Pada dimensi pertama, dimana item itemnya mengukur dimensi Difficult Identifying Feeling berada pada nomor item 1,3,6,7,9,13 dan I4 yang berjumlah 7 item. Pada hasil uji CFA telah menunjukan hasil yang terbukti valid, dimana P-Value pada Chi-Square $>0.05$ yaitu pada angka I. Pada ke 7 item pun terbukti muatan faktornya signifikan dan koefisien juga tidak ada yang $<0.5$. Dapat dilihat dari tabel 2.

Tabel 2. Indeks model fit dan Koefisien Muatan Faktor Dimensi DIF.

\begin{tabular}{|c|c|c|c|c|}
\hline \multicolumn{5}{|c|}{ Likelihood Ratio Chi-Square } \\
\hline \multicolumn{4}{|c|}{ Value } & 850.289 \\
\hline \multicolumn{4}{|c|}{ Degrees of Freedom } & I.6335 \\
\hline \multicolumn{4}{|c|}{ P-Value } & 1.0000 \\
\hline Item & Loading & E. Load. & S.E. P & -Value \\
\hline ALE1 & 1.397 & 0.231 & 6.041 & 0.000 \\
\hline $\mathrm{ALE} 3$ & 1.299 & 0.283 & 4.592 & 0.000 \\
\hline ALE6 & 1.838 & 0.287 & 6.394 & 0.000 \\
\hline ALE7 & 1.084 & 0.221 & 4.900 & 0.000 \\
\hline ALE9 & 2.146 & 0.374 & 5.734 & 0.000 \\
\hline ALE13 & 2.044 & 0.455 & 4.492 & 0.000 \\
\hline ALE 14 & 1.733 & 0.356 & 4.871 & 0.000 \\
\hline
\end{tabular}

Dari hasil pengujian untuk dimensi DIF di atas dapat disimpulkan bahwa semua item yang diniatkan untuk mengukur dimensi ini terbukti memenuhi asumsi unidimensional dan setiap itemnya signifikan dalam memenuhi fungsinya.

\section{Dimensi 2: DDF (Difficult Describing Feeling)}

Pada dimensi kedua, dimana item ini menguji dimensi difficult describing feeling berada pada nomor item 2, 4, II, I2 dan I7, yang berjumlah 5 item yang mengukur DDF. Pada hasil uji CFA telah menunjukan hasil yang terbukti valid, dimana P-Value pada Chi-Square $>0.05$ yaitu dengan P-value I.0000. Pada item I7 memiliki muatan faktor loading yang relatif lebih rendah tetapi hasilnya tetap terbukti signifikan, dan koefisien muatan faktor tidak ada yang menunjukkan angka $<0.5$. Meskipun tak sebaik pada dimensi DIF namun tak ada masalah validitas pada pengukuran dimensi DDF ini. Hasil CFA dapat dilihat pada tabel 3. 
Tabel 3. Indeks model fit dan Koefisien Muatan Faktor Dimensi DDF

\begin{tabular}{lcccc}
\hline \multicolumn{4}{c}{ Likelihood Ratio Chi-Square } \\
\hline \multicolumn{4}{c}{ Value } & 489.643 \\
Degrees of Freedom & 999 \\
P-Value & I.0000 \\
\hline Item & Loading & S.E. Load./S.E. P-V alue \\
A.LE2 & 2.286 & 0.754 & 3.032 & 0.002 \\
ALE4 & I.037 & 0.243 & 4.270 & 0.000 \\
ALEII & I.I96 & 0.275 & $4.35 \mathrm{I}$ & 0.000 \\
ALEI2 & I.04I & 0.229 & 4.553 & 0.000 \\
ALEI7 & $0.8 \mathrm{I} 5$ & 0.275 & $2.96 \mathrm{I}$ & 0.003 \\
\hline
\end{tabular}

Seperti halnya pada dimensi DIF maka pada dimensi inipun dapat disimpulkan bahwa berdasarkan hasil analisis CFA telah terbukti bahwa memang lima item yang ada adalah valid dan signifikan mengukur apa yang hendak diukur. Namun demikian ada sedikit catatan yang menunjukkan bahwa satu butir item yaitu nomor I7, yang koefisien loadingnya lebih rendah.

\section{Dimensi 3: EOT (Externally Oriented Thinking).}

Pada dimensi ketiga, dimana item menguji dimensi externally oriented thinkingyang berada pada nomor item 5, 8,I0, I5, I6, I8, I9 dan 20, yang berjumlah 8 item. Pada hasil uji CFA telah menunjukan hasil yang terbukti valid (model unidimensional fit dengan data), dimana P-Value pada Chi-Square $>0.05$ yaitu dengan P-value 1.0000. Namun terdapat tiga item yang bermasalah yaitu pada item item nomor 5 dan I9 yang memiliki koefisien muatan faktor negatif dan item nomor I0 yang koefisiennya tidak signifikan. Oleh sebab itu ketiga item tersebut kemudian di drop dan kemudian dilakukan kembali analisis CFA.. Adapun hasilnya telah terbukti fit dengan 5 item terakhir yaitu item 8, I5, I6, I8 dan 20, di mana model unidimensional dengan lima item ini menghasilkan nilai Chi-Square dengan P-Value $>0.05$ yaitu dengan P-value I.0000. Adapun koefisien muatan faktor untuk masing-masing item dapat dilihat pada Tabel 4.

Tabel 4. Indeks model fit dan Koefisien Muatan Faktor Dimensi EOT

\begin{tabular}{lllll}
\hline \multicolumn{3}{l}{ Likelihood Ratio Chi-Square } \\
\hline \multicolumn{4}{c}{ Value } & 919.229 \\
Degrees of Freedom & 65455 \\
P-Value & & & 1.0000 \\
\multicolumn{5}{l}{} \\
\end{tabular}

Sebagai kesimpulan dari uji validitas terhadap dimensi EOT ini, dari delapan item yang ada ternyata hanya empat item yairu nomor 8, I5, I6, dan 20, yang terbukti valid dalam mengukur dimensi EOT ini. Ada dua item yang bermuatan negatif serta ada dua butir item yang tidak signifikan. Khusus item nomor I8, 
koefisiennya jika dibulatkan adalah pada nilai batas yaitu 0.5 dan begitu pula nilai probabilitas untuk uji signifikannya adalah di parbatasan 0.05. Jadi meskipun valid dalam mengukur dimensi EOT namun kontribusinya terhadap skor EOT tidaklah signifikan secara statistik. Penelaahan lebih mendalam terhadap empat item yaitu dua yang koefisiennya negatif dan dua yang koefisiennya rendah (non signifikan) adalah sangat diperlukan. Sumber permasalahannya mungkin saja pada proses perterjemahannya ke dalam bahasa Indonesia, tetapi mungkin juga karena dalam konteks budaya Indonesia isi pertanyaan kurang atau tidak mewakili dimensi EOT dari konstruk alexithymia. Penelaahan isi item oleh ahli maupun kemungkinan penterjemahan yang lebih baik pada item item ini kiranya perlu dilakukan, atau penelitian lebih lanjut dengan populasi yang berbeda juga perlu dilakukan.

\section{Struktur Faktorial Internal Alexithymia}

Pada bagian terdahulu telah dilakukan uji validitas terhadap ketiga dimensi yang diteorikan oleh TAS-20 dalam pengukuran alexithymia. Langkah selanjutnya yang perlu dilakukan adalah menguji sebuah model (teori) dimana alexithymia terdiri dari tiga dimensi seperti yang telah disebutkan. Artinya, perlu dilakukan uji validitas struktur internal apakah alexithymia memang terdiri dari tiga dimensi seperti yang diteorikan. Dalam konteks penelitian ini, artinya perlu dilakukan analisis CFA dengan model tiga faktor yang sesuai teorinya, dengan menggunakan item yang telah terbukti valid, yaitu sebanyak 17 item (dalam hal ini item nomor I8 tetap diikutkan meskipun koefisiennya tidak signifikan). Adapun struktur faktor serta item untuk mengukurnya tetap mengikuti yang telah diteorikan pada Toronto Alexithymia Scale (TAS). Ternyata hasil pengujian CFA dengan model tiga faktor adalah sangat jauh dari model fit. Setelah berpuluh kali dilakukan modifikasi model terutama dengan cara membebaskan parameter "korelasi antar residual" (yang artinya pelanggaran asumsi "local independence" dan asumsi unidimensionalitas dalam setiap dimensi), akhirnya diperoleh model yang fit. Namun penulis tidak mencantumkan model tersebut di sini karena sangat sukar ditafsirkan, di mana bukan saja terdapat banyak korelasi partial antar butir soal (korelasi antar residual), tetapi juga banyak item yang memiliki loading yang signifikan pada lebih dari satu faktor. Artinya, tidak dapat ditunjukkan dengan jelas item mana mengukur faktor (dimensi) yang mana. Namun hasil dari proses ini dapat digunakan untuk mengidentifikasi item mana saja yang dapat dikelompokkan menjadi suatu faktor baru, dengan model di mana suatu item dimungkinkan memiliki muatan (mengukur) lebih dari satu faktor. Yang penting asalkan tidak ada korelasi antar residual. Sebagai hasil akhir diperolehlah model tiga faktor yang hanya menyisakan 13 item seperti disajikan pada Tabel 5 dan Gambar I.

Tabel 5. Model Fit untuk Model Tiga Faktor Hasil Modifikasi.

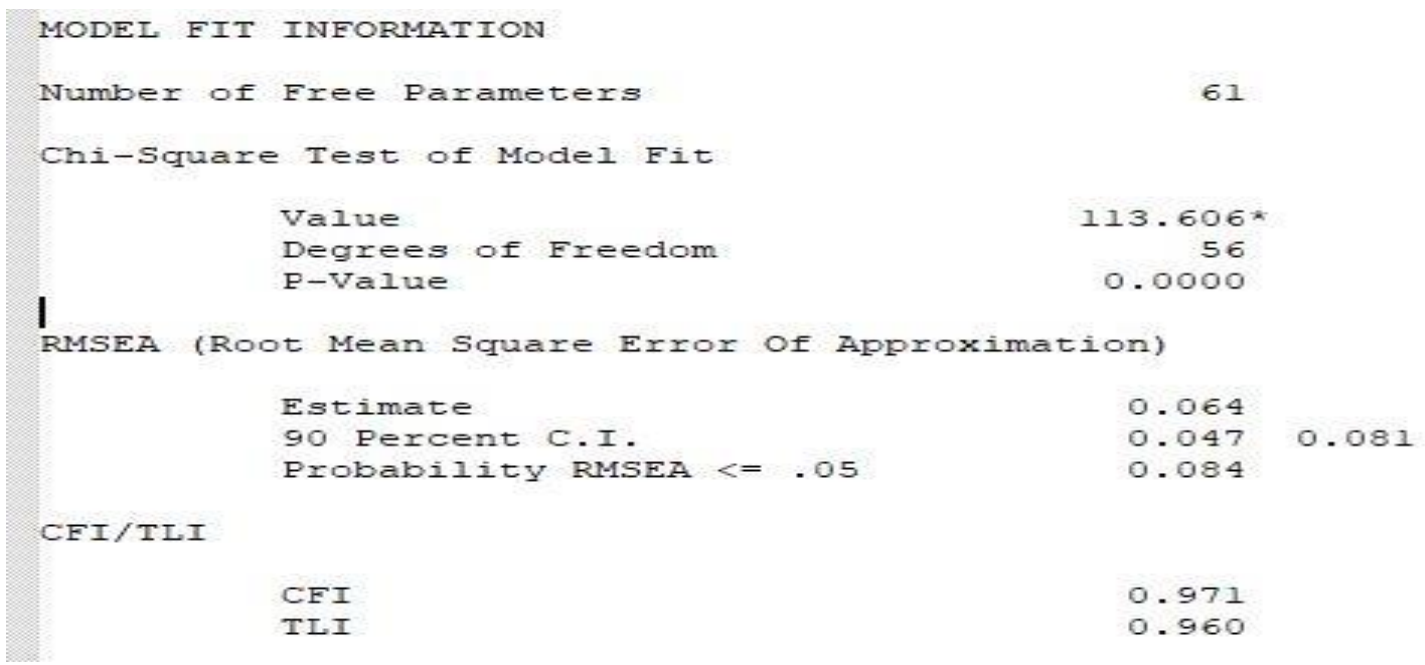




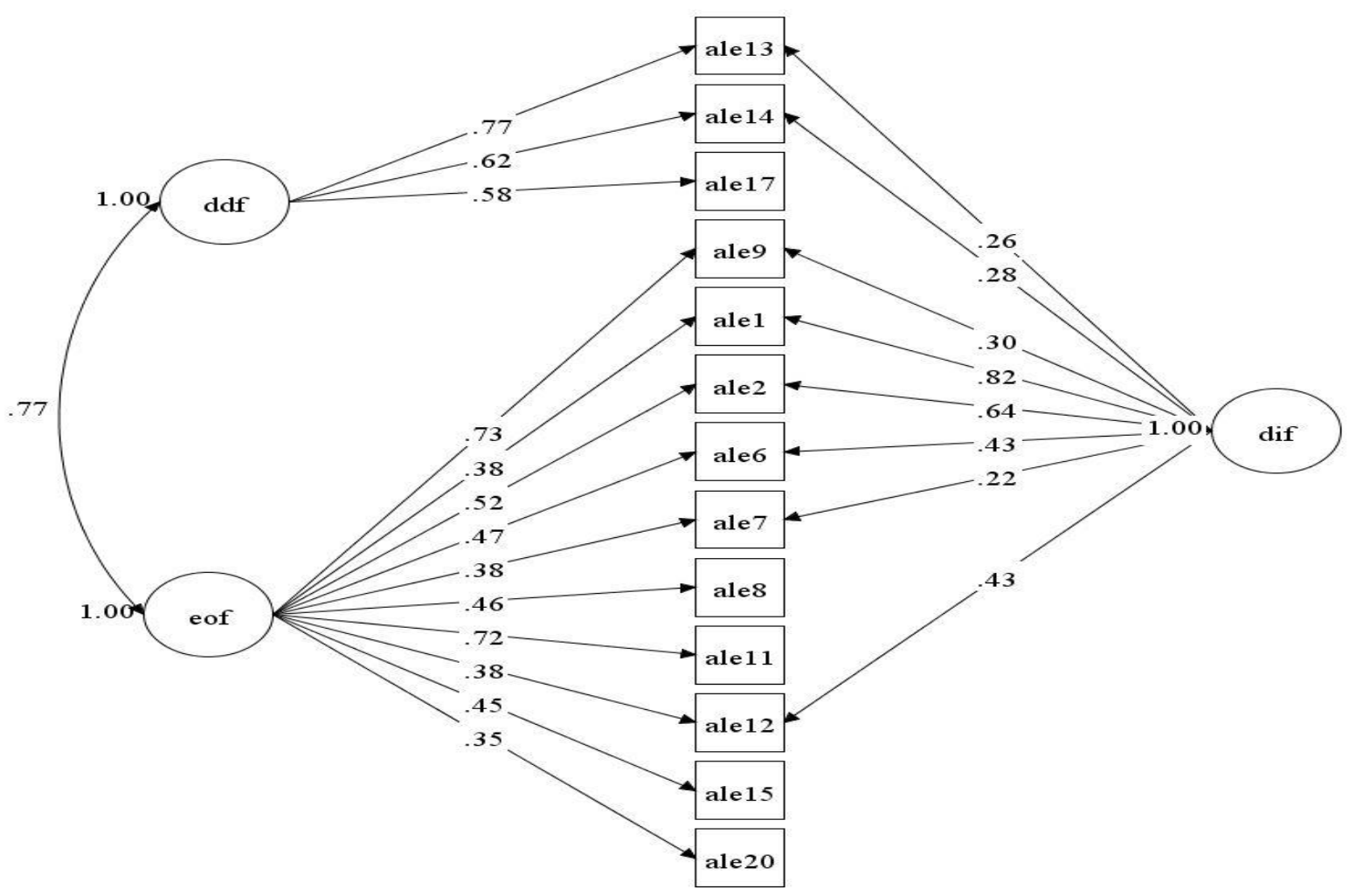

Gambar I. Model Tiga Faktor dari Alexithymia

Pada Tabel-5 terlihat bahwa RMSEA memiliki probabilitas yang $>0.05$ yang berarti tidak signifikan, dan model tiga faktor hasil modifikasi seperti pada Gambar-I adalah fit dengan data. Terlihat dalam Gambar-I bahwa eksistensi dari ketiga faktor semula (yang asli TAS-20) menjadi kabur dan tidak jelas. Bahkan dimensi DIF boleh dikatakan lenyap. Tidak ada satupun dari delapan item yang ditemukan signifikan dalam mengukur faktor ini yang memang hanya mengukur satu faktor saja.Semuanya memiliki muatan signifikan terhadap faktor yang lain pada saat yang sama. Begitu pula halnya dengan faktor DDF yang ternyata hanya didukung tiga item, namun hanya satu item yaitu item nomor I7, yang betul betul mengukur faktor ini saja. Dua item lainnya pada saat yang sama juga mengukur dimensi DIF. Hanya dimensi EOT yang relatif masih eksis karena masih ada tiga dari lima itemnya (yang valid) yang benar-benar hanya mengukur faktor ini saja, yaitu item nomor 8, I5, dan 20. Bahkan item nomor II yang dimaksudkan mengukur DDF, didalam struktur baru ini ternyata hanya mengukur EOT. Selain itu, sebagian besar item yang ada ( 9 dari I3) memiliki muatan signifikan pada faktor yang diberi label sebagai EOT dalam model yang baru ini. Jadi, jika mengikuti hasil model tiga faktor yang fit ini, EOT boleh dikatakan merupakan faktor umum (general factor) dari alexithymia. Apalagi jika melihat bahwa korelasi antara faktor EOT dengan DDF adalah sangat tinggi yaitu 0.77. Berdasarkan kesimpulan ini maka sangat masuk akal jika diteorikan bahwa sebenarnya alexithymia merupakan konsep generik yang berdimensi tunggal. Apalagi jika mengingat bahwa di dalam cara skoringnya alat ukur TAS ini menggunakan pendekatan teori tes klasik yaitu dengan menjumlahkan begitu saja sekor setiap item menjadi sekor tunggal yang menggambarkan tingkat alexithymia seseorang. Cara skoring seperti ini hanya bisa dibenarkan jika asumsi tes klasik terpenuhi yaitu selain asumsi unidimensionalitas juga ada asumsi bahwa seluruh item bersifat paralel sehingga bobotnya dianggap sama. Artinya, tidak diperlukan perhitungan "true score" sebab skor total dapat diperoleh dengan menjumlahkan skor setiap item tanpa pembobotan apapun. Oleh sebab itu, peneliti kemudian menguji model CFA dengan hanya satu faktor saja (model unidimensional) tetapi ditambah dengan konstrain di mana seluruh itemnya harus memiliki muatan faktor yang sama tingginya (asumsi paralel).Ternyata, jika item nomor I8 (yang sebelumnya ditemukan tidak 
signifikan) didrop, dapat diperoleh model yang sangat baik model fit nya terhadap data, seperti terlihat pada Tabel-6.

Tabel-6. Model Fit CFA Unidimensional dan Paralel

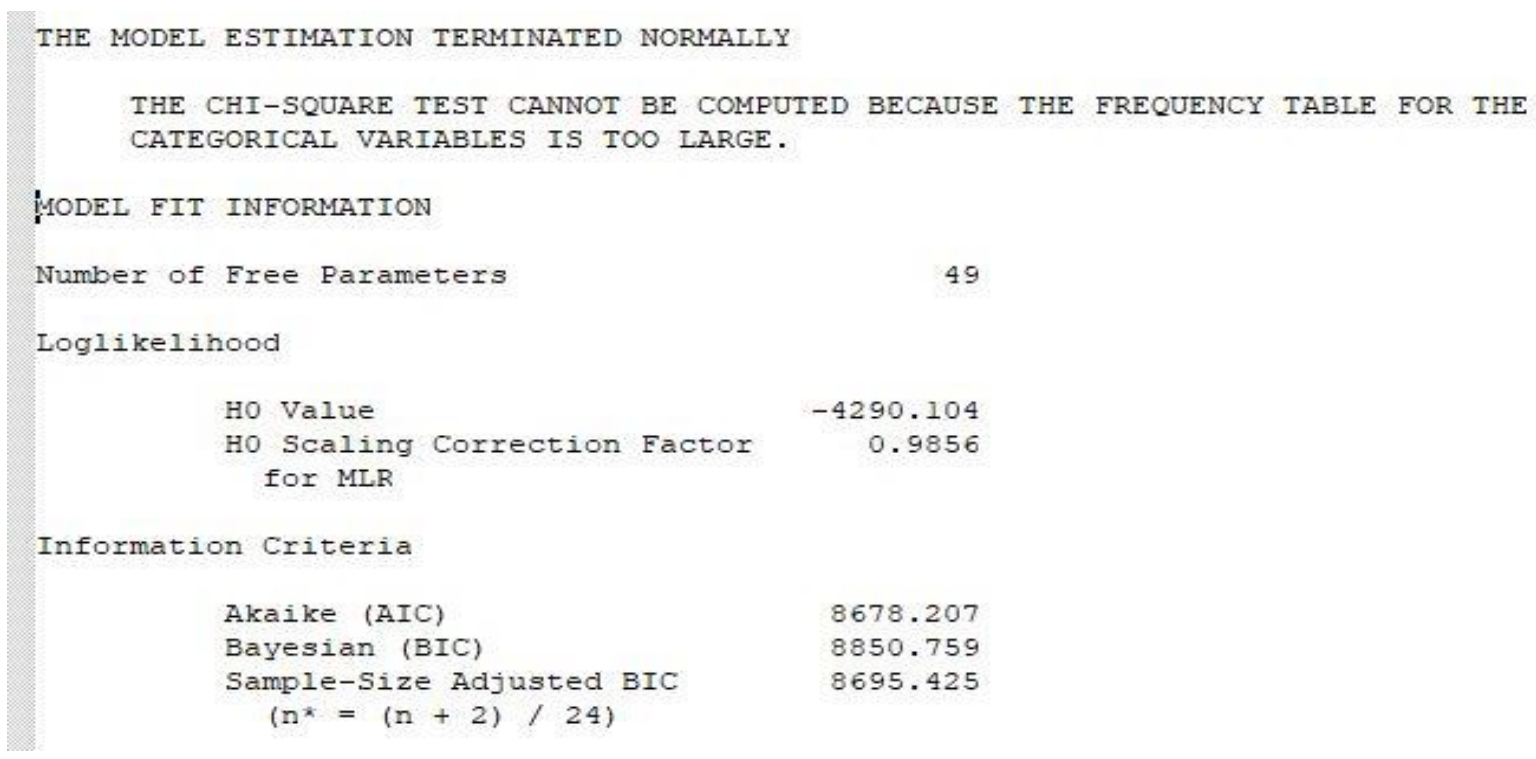

Pada model ini, karena ada konstrain bahwa semua item koefisien muatan faktor harus paralel, maka ketika dihitung dengan estimator maksimum likelihood biasa ternyata tak dapat diperoleh solusi karena proses perhitungan tidak konvergen. Oleh sebab itu digunakan metode MLR (Maximum Likelihood Robust), yang kalau itemnya banyak,apalagi jika kategori pada setiap item juga banyak, tidak dapat diperoleh Chi-square (karena perhitungannya terlalu kompleks). Tetapi alternatifnya adalah indeks "Scaling Correction Factor, yang jika nilainya satu atau sangat dekat dengan nilai I, berarti model yang diuji adalah fit dengan data. Dalam hal ini, indeks yang diperoleh adalah sebesar 0.9856 yang amat dekat dengan satu. Oleh sebab itu penulis menyimpulkan bahwa model satu faktor yang terdiri dari 16 item yang seluruh koefisien muatan faktornya paralel, adalah terbukti fit dengan data. Artinya, seluruh 16 item yang diuji adalah memang hanya mengukur satu konstruk saja yaitu alexithymia, dan semua item kemampuannnya sama dalam berkontribusi terhadap sekor alexithymia, yang dalam hal ini diperoleh koefisien sebesar I.20 dan signifikan secara statistik. Adapun kurva karakteristik dari setiap item (dengan menggunakan kategori ke empat di mana setiap item berbentuk skala likert dengan empat kategori jawaban), yang memang terbukti paralel dan menunjukkan daya pembeda yang cukup tinggi, dapat dilihat pada Gambar-2.

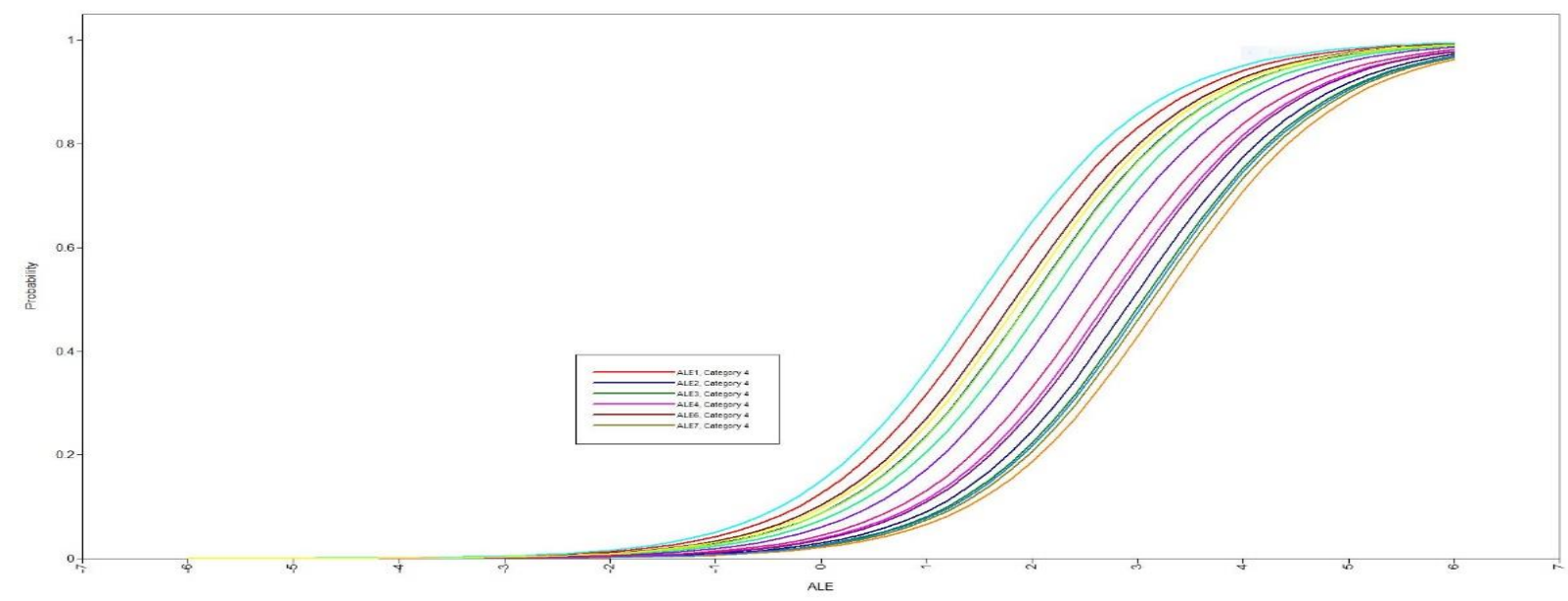

Gambar 2. Kurva Karakteristik Item yang Paralel. 
Pada gambar di atas jelas terlihat bahwa kurva item menanjak cukup curam yang berarti bahwa sumbangan setiap item adalah cukup tinggi dalam membedakan antara individu yang satu dengan lainnya yang diukur dengan instrumen ini. Artinya, semua item memiliki "discriminating power" yang tinggi. Ringkasnya, jika menggunakan 16 item yang terpilih di sini, maka penggunaan sekor mentah (hasil penjumlahan sekor item) adalah cukup valid dan terpercaya dalam mengukur tingkatan alexithymia seseorang. Sebagai kesimpulan, ialah bahwa: "meskipun dalam penyusunan item alat ukur Toronto Alexithymia Scale digunakan teori bahwa alexithymia terdiri dari tiga dimensi, namun di dalam penskorannya keberadaan dimensi tersebut dapat diabaikan”. Selain itu juga ditemukan bahwa hanya I6 dari 20 item yang ada, yang layak untuk digunakan.

\section{Penutup}

Penelitian ini menguji kembali apakah dimensi yang ada itu memang mewakili pengukuran terhadap alexithymia sesuai dengan definisi operasionalnya. Dari hasil pengujian untuk dimensi DIF di atas dapat disimpulkan bahwa semua item yang diniatkan untuk mengukur dimensi ini terbukti memenuhi asumsi unidimensional dan setiap itemnya signifikan dalam memenuhi fungsinya. Pada dimensi DDF pun dapat disimpulkan bahwa berdasarkan hasil analisis CFA telah terbukti bahwa memang lima item yang ada adalah valid dan signifikan mengukur apa yang hendak diukur. Namun demikian ada sedikit catatan yang menunjukkan bahwa satu butir item yaitu nomor I7, yang koefisien loadingnya lebih rendah. Pada dimensi EOT ini, dari delapan item yang ada ternyata hanya empat item yang terbukti valid dalam mengukur dimensi EOT ini. Ada dua item yang bermuatan negatif serta ada dua butir item yang tidak signifikan. Sumber permasalahannya mungkin saja pada proses perterjemahannya ke dalam bahasa Indonesia, tetapi mungkin juga karena dalam konteks budaya Indonesia isi pertanyaan kurang atau tidak mewakili dimensi EOT dari konstruk alexithymia.

Alexithymia merupakan konsep generik yang berdimensi tunggal. Di dalam cara skoringnya alat ukur TAS ini menggunakan pendekatan teori tes klasik yaitu dengan menjumlahkan begitu saja sekor setiap item menjadi sekor tunggal yang menggambarkan tingkat alexithymia seseorang. Meskipun dalam penyusunan item alat ukur Toronto Alexithymia Scale digunakan teori bahwa alexithymia terdiri dari tiga dimensi, namun di dalam penskorannya keberadaan dimensi tersebut dapat diabaikan. Selain itu juga ditemukan bahwa hanya I6 dari 20 item yang ada, yang layak untuk digunakan.

Dari hasil penelitian ini penulis menyampaikan beberapa saran berikut: I) Jika alat ukur Toronto Alexithymia Scale (TAS-20) akan digunakan di Indonesia, peneliti menyarankan untuk memperlakukannya sebagai instrumen yang murni bersifat unidimensional dan bukan terdiri dari tiga dimensi; 2) Ada empat dari 20 item TAS-20 yang tidak valid dan sebaiknya tidak digunakan, yaitu item nomor 5 dan 19 yang memiliki daya pembeda negatif, serta item nomor I0 dan I8 yang koefisien muatan faktornya terlalu rendah dan tidak signifikan; 3) Penggunaan sekor mentah (penjumlahan dari sekor item) yang prosedurnya cukup sederhana, boleh digunakan pada alat ukur TAS-20 (yang dalam hal ini bisa diberi nama TAS-16) karena telah lulus uji validitas konstruk dan uji paralelitas item. Dengan kata lain tidak diperlukan estimasi terhadap "true score" kecuali untuk keperluan analisis data dalam penelitian; 4) Jika diinginkan bentuk yang asli dari TAS-20 yang terdiri dari 20 item, maka perlu disusun empat item pengganti dengan pemahaman dan penerjemahan yang lebih baik khususnya pada empat item yang di drop; 5) Walaupun penelitian ini telah menggunakan metodologi yang hasil estimasi parameternya relatif bersifat "sampling invariance" yaitu Confirmatory Factor Analysis (CFA) dengan pendekatan Item Response Theory (IRT), namun sangat disarankan agar dilakukan penelitian lebih lanjut dengan menggunakan sampel yang lebih besar serta lebih bervariasi, dan juga dengan prosedur penerjemahan item yang lebih sempurna, misalnya dengan melakukan "back translation"; 6) Untuk penelitian selanjutnya dapat memberi keragaman pada populasi sampel, tidak hanya mahasiswa tetapi bisa masyarakat umum yang terpenting mereka masih dalam kategori dewasa awal; 7) Penelaahan isi item oleh ahli maupun kemungkinan penterjemahan yang lebih baik pada item item ini kiranya perlu dilakukan. 8) Peneliti 
menyarankan beberapa intervensi dibawah ini untuk meminimalisir gangguan alexithymia dikalangan dewasa awal khususnya mahasiswa, kepada pengelola bidang pendidikan yaitu pihak kampus dimana populasi dewasa awal berada pada mahasiswa kampus, diharapkan peka terhadap fenomena psikologis untuk secara sadar selektif, jika diketahui mahasiswa yang memiliki alexithymia terutama jika mahasiswa tersebut dalam bidang psikologi, nantinya akan menghambat kemampuan mereka dalam mengobati pasien psikiatri.

\section{Daftar Pustaka}

Bagby, R. M., Parker, J. D., \& Taylor, G. J. (1994). The twenty-item Toronto Alexithymia Scale-I. Item selection and cross-validation of the factor structure. Journal of psychosomatic research, $38(\mathrm{I}), 23-32$.

Bermond, B. and Vorst, H. C. (1998). 'Validity and reliability of Bermond \pm Vorst Alexithymia Questionnaire', Manuscript in preparation. The Netherlands: University of Amsterdam.

De Muzan, M. (1974). Psychodynamic mechanisms in psychosomatic symptomformation. Journl of Psychotherapy and psychosomatics, 23(I-6), I03-IIO.

Fischer, A. R., \& Good, G. E. (I997). Men and psychotherapy: An investigation of alexithymia, intimacy, and masculine gender roles. Journal of Psychotherapy: Theory, Research, Practice, Training, 34(2), I60.

Joreskog, K.G. dan Sorbom, D. (I996). LISREL 8: Users Reference Guide. Chicago: Scientific Software International In.

Muthén, L.K. and Muthén, B.O. (20I2). Mplus User's Guide. Seventh Edition. Los Angeles, CA: Muthén \& Muthén.

Krystal, H. (1979). Alexithymia and psychotherapy. American journal of psychotherapy, 33(I), I7-3I.

Sifneos, P. E. (I973). The prevalence of 'alexithymic'characteristics in psychosomatic patients. Psychotherapy and psychosomatics, 22(2-6), 255-262.

Taylor, G. J., Ryan, D., \& Bagby, M. (1985). Toward the development of a new self-report alexithymia scale. Psychotherapy and psychosomatics, 44(4), I9I-I99.

Thompson, J. (2009). Emotionally Dumb: An Overview of Alexithymia. Australia: Soul Books.

Timoney, L. R., \& Holder, M. D. (2013). Emotional processing deficits and happiness: Assessing the measurement, correlates, and well-being of people with alexithymia. US: Springer Science \& Business Media.

Taylor, G. J., Bagby, R. M., \& Parker, J. D. (1989). Disorders of affect regulation: Alexithymia in medical and psychiatric illness. UK: Cambridge University Press.

Hendryx, M. S., Haviland, M. G., \& Shaw, D. G. (I99I). Dimensions of alexithymia and their relationships to anxiety and depression. Journal of personality assessment, 56(2), 227 - 237.

Manninen, M., Therman, S., Suvisaari, J., Ebeling, H., Moilanen, I., Huttunen, M., \& Joukamaa, M. (20I I). Alexithymia is common among adolescents with severe disruptive behavior. Journal of nervous and mental disease, I99(7), 506-509.

Nemiah, J. C. (1976). Alexithymia: a view of the psychosomatic process. Modern trends in psychosomatic medicine, 3, 430-439. 